\title{
Description and Analysis of Genetic Diversity among Squash Accessions
}

\author{
Athanasios L. Tsivelikas ${ }^{1}$, Olga Koutita ${ }^{2}$, Anastasia Anastasiadou ${ }^{1}$, George N. Skaracis ${ }^{3}$, \\ Ekaterini Traka-Mavrona ${ }^{4}$, and Metaxia Koutsika-Sotiriou ${ }^{1 *}$ \\ ${ }^{1}$ Aristotle University of Thessaloniki; Faculty of Agriculture; Laboratory of Genetics and Plant Breeding; 54124 \\ Thessaloniki - Greece. ${ }^{2}$ Hellenic Sugar Industry S.A.; Laboratory of Molecular Biology and Diagnostics; 574 00; \\ Sindos - Greece. ${ }^{3}$ Agricultural University of Athens; Laboratory of Plant Breeding and Biometry; 118 55; Athens - \\ Greece. ${ }^{4}$ National Agricultural Research Foundation; Agricultural Research Center of Macedonia and Thrace; 570 \\ 01; Thermi; Thessaloniki - Greece
}

\begin{abstract}
In this work, the part of the squash core collection, maintained in the Greek Gene Bank, was assessed using the morphological and molecular data. Sixteen incompletely classified accessions of the squash were characterized along with an evaluation of their resistance against two isolates of Fusarium oxysporum. A molecular analysis using Random Amplified Polymorphic DNA (RAPD) markers was also performed, revealing high level of polymorphism. To study the genetic diversity among the squash accessions, a clustering procedure using Unweighed Pair Group Method and Arithmetic Average (UPGMA) algorithm was also adopted. Two independent dendrograms, one for the morphophysiological and one for molecular data were obtained, classifying the accessions into two and three main clusters, respectively. Despite the different number of the clusters there were many similarities between these two dendrograms, and a third dendrogram resulting from their combination was also produced, based on Gower's distance and UPGMA clustering algorithm. In order to determine the optimal number of clusters, the upper tail approach was applied. The more reliable clustering of the accessions was accomplished using RAPD markers as well as the combination of the two different data sets, classifying the accessions into three significantly different groups. These groups corresponded to the three different cultivated species of C. maxima Duch., C. moschata Duch., and C. pepo L. The same results were also obtained using Principal Component Analysis.
\end{abstract}

Key words: Cluster analysis, Gower's distance, morphophysiological characteristics, Principal Component Analysis, RAPD markers, winter squash

\section{INTRODUCTION}

In the genus Cucurbita, there are five domesticated (C. argyrosperma Huber, C. ficifolia Bouché, C. maxima, C. moschata and C. pepo) and approximately ten wild species (Robinson and Decker-Walters, 1997, p. 71). Most species originated in Mexico, with only a few species, including $C$. maxima, being native to South
America. Certain morphological and physiological characteristics of these species such as the fast and indeterminate growth, developmental plasticity in response to the environmental conditions as well as the genetic diversity at the gene level, lead to the assumption that Cucurbita represents one of the most primitive genus in the plant kingdom. Further support suggesting that the squash and pumpkin are among the most ancient of the

\footnotetext{
*Author for correspondence: koutsika@agro.auth.gr
} 
cultivated plants comes from the archaeological evidences: the seeds and rinds of $C$. pepo have been found at the sites dating 10,000-30,000 B.C. in Florida, 7,000-9,000 B.C. in Mexico and approximately 5,000 B.C. in Illinois (Robinson and Decker-Walters, 1997).

Only three domesticated species, C. pepo, $C$. maxima and $C$. moschata are recorded in Greece. Zucchini cultivars (C. pepo) are by far the most widely grown types of squash, either in the field or under the plastic greenhouse conditions for early crop production. Their immature fruits are highly appreciable by the consumers and are known as summer squash because they are consumed mainly during the summer. On the contrary, the winter squash (Cucurbita spp.) are of limited economic value with occasionally important role in the areas where the cultivation systems are not intensive. Their mature fruits can be long stored and consumed mainly during the winter in the traditional foods and cakes.

In Greece, the cultivation of the winter squash is practiced mostly in small orchards for selfconsumption or sale at the local markets. The majority of the production is based on landraces maintained for the years by the local farmers. Although not so popular as the summer squash, neglected landraces of the winter squash possess various agronomic and horticultural characteristics of interest, resistance against the pests and diseases in particular, rendering them a valuable genetic source for the breeding programs. The Agricultural Research Center of Macedonia and Thrace (A.R.C.M.T.) started few years ago a program for the exploitation of these winter squash accessions as the rootstocks for the melon cultivars (Traka-Mavrona et al., 2000). In addition, the Greek Gene Bank initiated an effort aiming at collecting Cucurbita spp. landraces from all the areas of the continental and insular Greece. A morphological and molecular characterization of this germplasm is needed, along with the tests for the biotic and abiotic stress tolerance so that this collection becomes useful for the breeders and farmers.

The few studies concerning the morphological diversity among the landraces of the squash from different centers of diversity such as Cuba, Korea and Puerto Rico have revealed a great variability of the squash types (Rios et al., 1997; Chung et al., 1998; Wessel-Beaver, 1998). Recently, Ferriol et al. (2004a, 2004b) also found a considerable morphological variability among different landraces of $C$. moschata and $C$. maxima, especially in the fruit shape, ribbing and size.

There are also quite a few studies concerning the molecular analysis in Cucurbita species. The RAPD markers were used to analyze the genetic diversity among $C$. moschata landraces from Korea, southern Africa and other geographical origins (Youn and Chung, 1998; Baranek et al., 2000; Gwanama et al., 2000). In all the cases, the accessions were grouped according to the agroclimatic regions of origin and not according to the morphological traits. Ferriol et al. (2003) studied the genetic diversity among 19 Spanish accessions of $C$. maxima using two different molecular marker types: Sequence Related Amplified Polymorphism (SRAP) and RAPD. More recently Ferriol et al. (2004a, 2004b), in addition to the morphological analysis, employed the SRAP and AFLP (Amplified Fragment Length Polymorphism) molecular markers for analyzing the diversity among a large number of $C$. moschata and C. maxima landraces.

In all the cases, the results from the molecular analysis were correlated with the morphological characteristics. However, very few studies have attempted to compare results derived from the individual versus combined data sets not only for Cucurbita species, but also for other crop species (Franco et al., 1997; Russell et al., 1997; AjmoneMarsan et al., 1998). In addition, there are almost very few analyses combining data sets of different nature, i.e. qualitative and quantitative morphological data, or morphological and molecular marker data (Franco et al., 1997; Franco et al., 1998; Franco et al., 2001). Such kind of analyses could provide evidence whether a better estimate of the genetic diversity is obtainable and also whether the total evidence is within the confidence limits of evidence from the individual data sets.

The aim of the present work was to analyze the genetic diversity of a part of the squash core collection, maintained in the Greek Gene Bank. The accessions were characterized using the morphological attributes along with an evaluation of the resistance against two isolates of Fusarium oxysporum. In addition a molecular analysis using the RAPD markers was also employed. The comparison between the relationships obtained by both the data sets (morphophysiological and molecular), as well as the possibility of combining the different data sets are discussed. 


\section{MATERIALS AND METHODS}

\section{Plant material}

Sixteen Greek accessions of the squash were used (Table 1). Thirteen of them belonged to Cucurbita spp. collection of the Greek Gene Bank and have been collected from different areas of the continental and insular Greece. Although registered as winter squashes, these accessions had not been completely classified. Three breeding lines from A.R.C.M.T., recently affiliated in Gene Bank, were also used. Lines 21 and 221 belonged to $C$. moschata and C. maxima, respectively, while line 224 was assigned (with no complete certainty) as $C$. maxima.

Morphological and physiological characteristics Five plants per accession were evaluated for the morphological characteristics, based on UPOV's squash descriptor list (UPOV, 1996). Thirty eight morphological characteristics were assessed, starting from the young seedling till the stage of mature fruit and the extraction of the seed (Table 2). Data were scored using a metric scale of integer numbers between 1-9 according to the descriptor list. In addition, all the accessions were evaluated for their resistance against two pathotypes of Fusarium oxysporum, i.e. F. oxysporum f.sp. melonis (Leach and Currence) W.C.Snyder and H.N. Hans (Leach and Currence,
1938), and $F$. oxysporum f.sp. radiciscucumerinum D.J. Vakalounakis (Vakalounakis, 1996) (Table 2). The plants were grown for one week in the seed beds composed of the peat moss and perlite at a ratio of 10:1, and were transplanted to the pots when they had one true leaf. Prior to the transplanting, the roots were dipped in a conidial suspension of $10^{6}$ conidia/ml. Then the inoculated plants were irrigated with a spore suspension of the same density three times, once a day for the following three days after transplanting. The inoculated plants were kept in a growth chamber at $23{ }^{\circ} \mathrm{C}$, RH $70 \%$ and $16 / 8$ of light and darkness. Two weeks after the inoculation, the response of the plants was evaluated using a metric scale from 0 to 3 (0: no symptoms; 1: slight yellowing of bottom leaves; 2 : leaves with dead areas, leaf senescence, yellow spots on the upper leaves; 3: dead plants) (Koutsika-Sotiriou et al., 2004).

\section{RAPD analysis}

For RAPD analysis random 10-mer primers (Operon Technologies Inc., Alameda, CA) were used. The amplification was carried out in $25 \mu \mathrm{l}$ reaction mix containing about $25 \mathrm{ng}$ of genomic DNA, $0.2 \mathrm{mM}$ of each dNTP, $0.2 \mu \mathrm{M}$ of primer, 2 $\mathrm{mM}$ of $\mathrm{MgCl}_{2}$ and $1 \mathrm{U}$ of Taq DNA polymerase (Invitrogen) with supplied buffer.

Table 1 - Squash accessions used in the study.

\begin{tabular}{ccccc}
\hline Col. Number & Accession code & Local name & Collection site & Cucurbita species \\
\hline $18 / 99$ & 18 & - & Samos & C. moschata \\
$28 / 99$ & 28 & - & Samos & C. moschata \\
$48 / 99$ & 48 & Liries & Samos & C. pepo \\
$51 / 99$ & 51 & Glykokolokitha & Samos & C. pepo \\
$54 / 99$ & 54 & Ntabouradia & Ikaria & C. moschata \\
$55 / 99$ & 55 & - & Ikaria & C. pepo \\
$147 / 99$ & 147 & - & Crete (Rethimno) & C. moschata \\
$151 / 99$ & 151 & - & Crete (Heracleum) & C. moschata \\
$183 / 99$ & 183 & Glykokolokitha & Crete (Lasithi) & C. moschata \\
$231 / 99$ & 231 & Glykokolokitha & Peloponnisos (Lakonia) & C. moschata \\
$252 / 99$ & 252 & - & Evros (Soufli) & C. moschata \\
$293 / 99$ & 293 & Pnigmeno & Pella (Almopia) & C. moschata \\
$508 / 99$ & 508 & - & Pella (Almopia) & C. pepo \\
- & $21^{*}$ & Kalkabaki & Chalkidiki (Galatista) & C. moschata \\
- & $221^{*}$ & Kolokitha Lefki & Thessaloniki (Thermi) & C. maxima \\
- & $224^{*}$ & Kolokitha Kokkini & Thessaloniki (Livadi) & C. maxima \\
\hline
\end{tabular}

*Breeding lines from A.R.C.M.T. 
Table 2 - Morphological and physiological characteristics evaluated in 16 squash accessions.

\begin{tabular}{|c|c|}
\hline Characteristic & Code \\
\hline Shape of cotyledon & v1 \\
\hline Growth habit & v2 \\
\hline Stem color & v3 \\
\hline Size of leaf blade & $\mathrm{v} 4$ \\
\hline Intensity of leaf color of upper side of leaf blade & v5 \\
\hline Marbling presence & v6 \\
\hline Petiole length & v7 \\
\hline Petiole thickness & v8 \\
\hline Sepal length of female flower & v9 \\
\hline Intensity of orange color of pistil (before opening) & v10 \\
\hline Pedicel length of male flower & v11 \\
\hline Pedicel diameter of male flower & v12 \\
\hline Intensity of green color of pedicel & v13 \\
\hline Hairiness of pedicel of male flower & v14 \\
\hline Sepal length of male flower & v15 \\
\hline Main color of fruit pedicel & v16 \\
\hline Fruit size & v17 \\
\hline Fruit length & v18 \\
\hline Fruit diameter & v19 \\
\hline Fruit shape in longitudinal section & v20 \\
\hline Shape of fruit stalk end & v21 \\
\hline Shape of fruit apical end & v22 \\
\hline Fruit grooves & v23 \\
\hline Distance between fruit grooves & v24 \\
\hline Number of colors of fruit skin & v25 \\
\hline Main color of fruit skin & v26 \\
\hline Intensity of main color of fruit skin & v27 \\
\hline Secondary color of fruit skin & v28 \\
\hline Distribution of secondary color of fruit skin & v29 \\
\hline Texture of fruit surface & v30 \\
\hline Thickness of fruit flesh & v31 \\
\hline Main color of fruit flesh & v32 \\
\hline Intensity of main color of fruit flesh & v33 \\
\hline Seed size & v34 \\
\hline Seed shape & v35 \\
\hline Seed surface & v36 \\
\hline Seed color & v37 \\
\hline Weight of 1000 dry seeds & v38 \\
\hline Resistance against $F$. oxysporum f.sp. radicis-cucumerinum & v39 \\
\hline Resistance against $F$. oxysporum f.sp. melonis & $\mathrm{v} 40$ \\
\hline
\end{tabular}

The DNA amplification was performed in a PTC 200 thermal cycler (MJ Research), according to the following thermal profile: initial denaturation at $94{ }^{\circ} \mathrm{C}$ for $3 \mathrm{~min}$, followed by 40 cycles of denaturation at $94{ }^{\circ} \mathrm{C}$ for $45 \mathrm{~s}$, annealing at $35{ }^{\circ} \mathrm{C}$ for $1.5 \mathrm{~min}$ and extension at $72{ }^{\circ} \mathrm{C}$ for $1.5 \mathrm{~min}$, followed by final extension at $72{ }^{\circ} \mathrm{C}$ for $3 \mathrm{~min}$. The amplification products were separated in $1.5-2$ $\%$ agarose gel and detected by staining with ethidium bromide (Sambrook et al., 1989). The gels were photographed under UV light. Each
PCR reaction was run in duplicate, and only well defined and reproducible bands were analyzed.

\section{Data analysis}

Based on the evaluation of the morphophysiological characteristics, a raw data matrix was created. A pair wise Euclidean distance matrix, the most commonly applied procedure for these kind of traits (Mohammadi and Prasanna, 2003), was analyzed by the UPGMA clustering procedure of the software NTSYS pc version 2.1 (Rohlf, 2000). The raw data matrix was used to 
perform the ordination analysis (Principal Component Analysis - PCA) with the same software. For the RAPD markers, each polymorphic band in every sample was scored as a binary character with the value of 1 for the presence and 0 for the absence of the band, and a data matrix was created. The DNA bands of the identical gel migration were assumed to represent the same allele at a locus. Only reproducible and clearly visible bands were scored. The bands detected in all the plant samples at the same position (monomorphic) were excluded from the analysis.

Nei's (1972) genetic distances were calculated based on the gene frequencies data and a dendrogram was constructed using the UPGMA clustering procedure. The gene frequencies data were also used for the PCA analysis. Mantel's test for the matrix correspondence was used to estimate the correlation between different matrices (Mantel, 1967). To combine two different set of data (morphophysiological characters and RAPD markers), the gene frequencies were transformed to continue data using the function arcsine square root. A common data matrix was produced including both the gene frequencies (quantitative variables) and morphophysiological characteristics scores (qualitative variables). A dendrogram was produced by the use of Gower's distance (Gower, 1971), which could be applied in the cases of quantitative and qualitative variables combination (Franco et al., 1997). Gower's distance is a metric distance which takes values between $d=0$ (maximum similarity) and $d=1$ (minimum similarity). The Gower's distance between two individuals ( $i$ and $j$ ) is defined as:

$$
D_{i j}=\frac{\sum_{k=1}^{p} w_{i j k} * d_{i j k}}{\sum_{k=1}^{p} w_{i j k}}
$$

where: $d_{i j k}$ : the contribution of the $k$ th variable to the total distance between individuals $i$ and $j$.

$w_{i j k}:$ is a weight given to the $i j k$ comparison, assigning values of ' 1 ' for a valid comparison and ' 0 ' for invalid comparisons.
One accession of Cucumis melo L. was used as the outgroup. The fitness of each dendrogram with the respective distance matrix was evaluated using the cophenetic value. To define the optimal number of the clusters for each dendrogram, the approach of upper tail criterion at confidence level $\alpha=0.05$ was used (Milligan and Cooper, 1985; Franco et al., 1997).

\section{RESULTS}

\section{Morphophysiological characteristics}

All the accessions studied exhibited a high variability for all the morphophysiological characteristics. A wide range of resistance among the accessions to $F$. oxysporum was detected. Specifically, for $F$. oxysporum f.sp. radiciscucumerinum, $68.75 \%$ of the accessions were totally resistant, while $6.25 \%$ of the accessions were totally susceptible. For $F$. oxysporum f.sp. melonis, $87.5 \%$ of the accessions were resistant, while the rest $12.5 \%$ of the accessions exhibited some symptoms but plants managed to survive. The PCA provided seven principal components, explaining $>80 \%$ of total variation (Table 3 ). The first component accounted for $25.36 \%$ of the total variation, and grouped the accessions on the basis of the morphological characteristics of the male flower and resistance against $F$. oxysporum f.sp. melonis. The second component accounted for $20.43 \%$ of the total variation and grouped the accessions according to the seed size and weight, leaf blade characters and fruit shape (Fig. 1a).

Fig. 1b showed the two-dimensional plot for the sixteen squash accessions using the first two principal components, which explained $45.79 \%$ of the total variation. According to this procedure, the accessions were separated into two groups. The first group was composed of the accessions 221 and 224, while the second group included all the remaining accessions. 
$\underline{\text { Table } 3 \text { - Principal Component Analysis of morphophysiological traits. }}$

\begin{tabular}{lccc}
\hline PCs & Eigenvalue & Percent $(\%)$ of total variation & Cumulative percent (\%) of total variation \\
\hline 1 & 10.15 & 25.37 & 25.37 \\
2 & 8.17 & 20.43 & 45.79 \\
3 & 4.62 & 11.54 & 57.33 \\
4 & 3.23 & 8.08 & 65.41 \\
5 & 2.67 & 6.67 & 72.08 \\
6 & 2.37 & 5.93 & 78.00 \\
7 & 2.06 & 5.15 & 83.16 \\
\hline
\end{tabular}
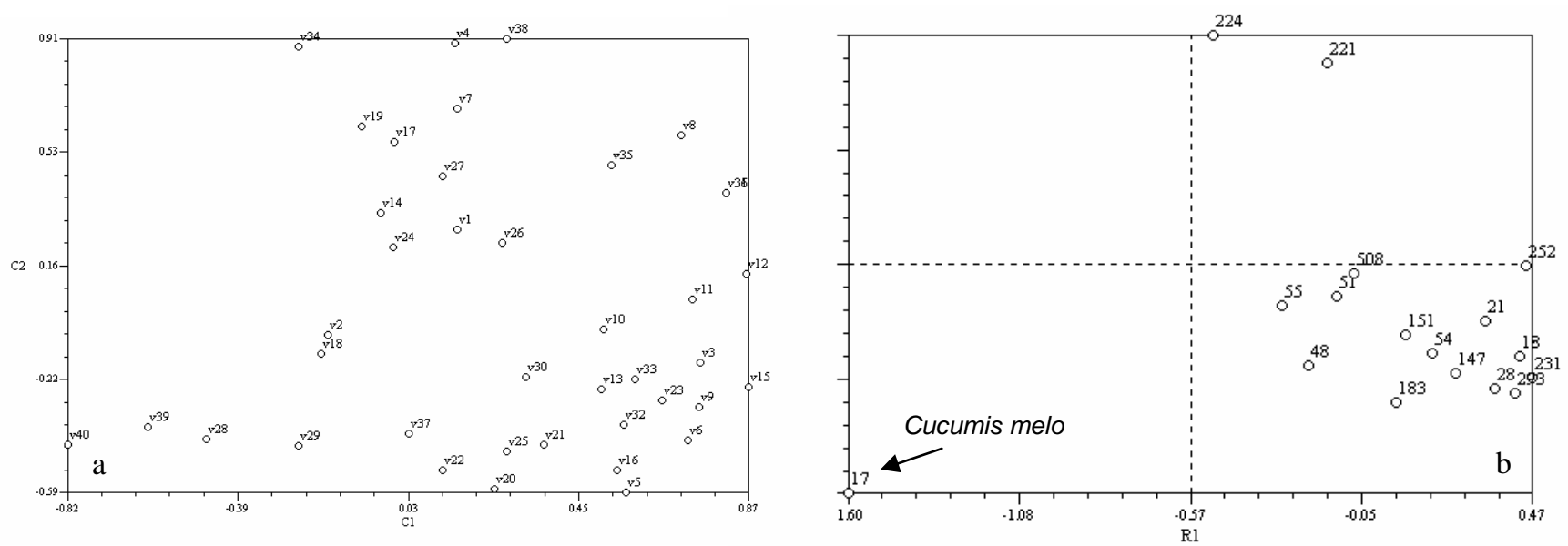

Figure 1 - a: Two dimensional plot showing the relationships among 40 morphophysiological characteristics of the 16 squash accessions. b: Two dimensional plot showing the correlations among the 16 squash accessions according to PCA using morphophysiological characteristics

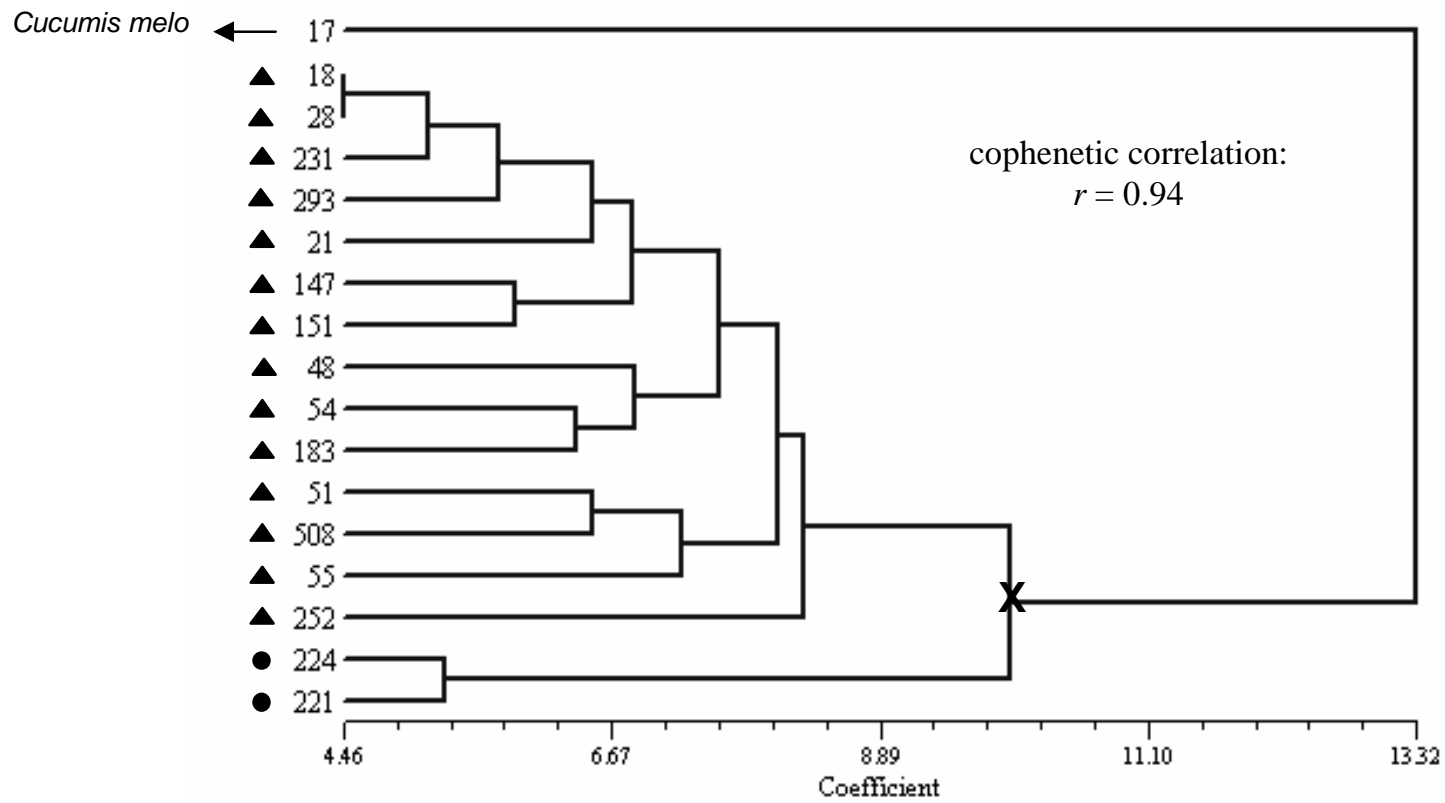

Figure 2 - Dendrogram showing the clustering of 16 squash accessions based on morphophysiological data (Euclidean distances, UPGMA method). 
The UPGMA method, based on 'Euclidean distances', grouped the accessions according to the dendrogram of Fig. 2. The dendrogram showed a high degree of fit with the respective distance matrix (cophenetic correlation: $r=$ 0.94). After the application of upper tail approach for the confidence level $\alpha=0.05$, the best partition was found to give two groups. The first one consisted of two accessions (221 and 224 ) and the second one included all other.

\section{Molecular characterization}

For the RAPD analysis, seven random primers were amplified with the DNA from five individual plants of each accession. Totally, 117 bands were detected with an average of 16.7 bands per primer. Out of these, 114 (97.44\%) were polymorphic. Thirteen bands were unique amplification products, which distinguished each accession from the other tested accessions.
There was only one case, where a specific band, present in all other accessions, was absent in a single accession (Table 4).

Eight principal components explained more than $80 \%$ of the total variation (Table 5). The first two classified the accessions into three groups, the first including the accessions 221 and 224, the second the accessions 48, 51, 55 and 508, and the third the accessions 18, 21, 28, 54, 147, 151, 183, 231, 252 and 293 (Fig. 3).

The dendrogram, according to UPGMA, based on Nei's genetic distance, is given in Fig. 4. Following the application of the upper tail approach for the confidence level $\alpha=0.05$, the accessions were classified into the same three, significantly different, groups. The cophenetic correlation of the dendrogram to the respective genetic distances matrix was high $(r=0.93)$.

Table 4 - RAPD polymorphism among the 16 squash accessions.

\begin{tabular}{ccccc}
\hline Primer & $\begin{array}{c}\text { Total number of } \\
\text { bands }\end{array}$ & $\begin{array}{c}\text { Number of } \\
\text { polymorphic bands }\end{array}$ & Polymorphism (\%) & Unique products \\
\hline OPAG-11 & 9 & 9 & 100.0 & - \\
OPAG-18 & 14 & 14 & 100.0 & 2 \\
OPAC-1 & 22 & 22 & 100.0 & 4 \\
OPAC-3 & 22 & 17 & 100.0 & 1 \\
OPAC-4 & 18 & 14 & 94.4 & 1 \\
OPAL-4 & 14 & 16 & 100.0 & 3 \\
OPAL-6 & 18 & & & 28.8 \\
\hline
\end{tabular}

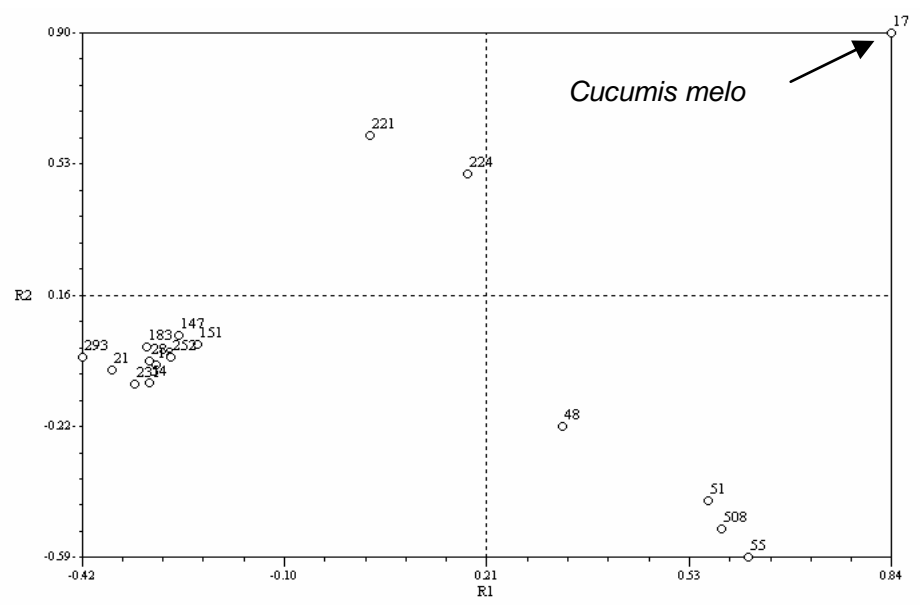

Figure 3 - The relationships among 16 winter squash accessions according to PCA analysis on RAPD data. 
Table 5 - Principal Component Analysis of RAPD markers.

\begin{tabular}{cccc}
\hline PCs & Eigenvalue & Percent (\%) of total variation & Cumulative percent (\%) of total variation \\
\hline 1 & 22.31 & 17.99 & 17.99 \\
2 & 17.89 & 14.43 & 32.42 \\
3 & 14.62 & 11.79 & 44.22 \\
4 & 14.04 & 11.32 & 55.54 \\
5 & 10.33 & 8.33 & 63.87 \\
6 & 9.22 & 7.43 & 71.30 \\
7 & 6.83 & 5.51 & 76.81 \\
8 & 6.65 & 5.37 & 82.17 \\
\hline
\end{tabular}

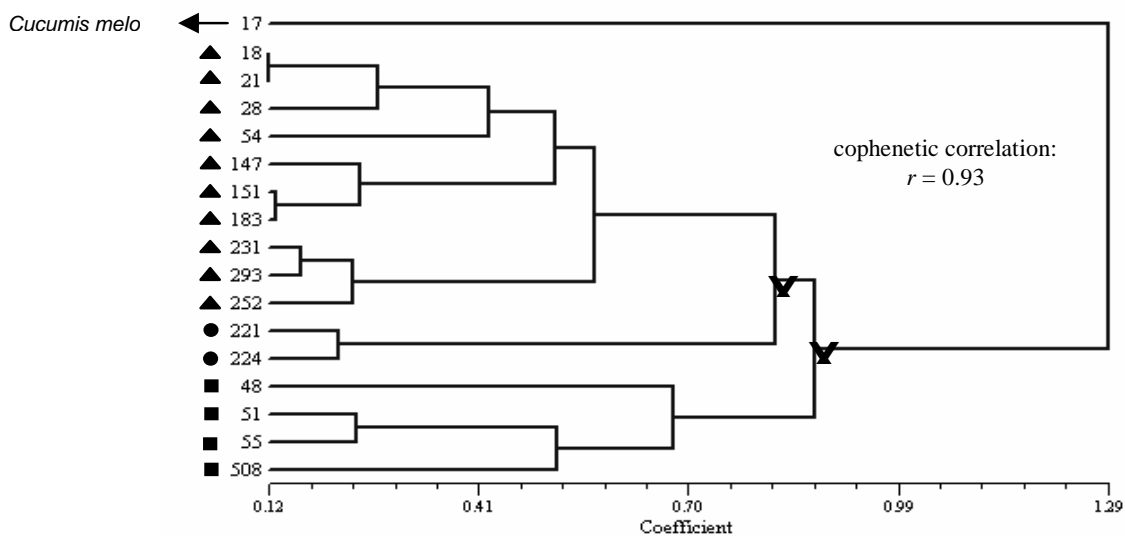

Figure 4 - Dendrogram of 16 squash accessions according to UPGMA analysis (Nei's (1972) genetic distances, UPGMA method).

Combining morphophysiological and molecular

\section{data}

Mantel's test on the various genetic distance matrices was highly significant $(r=0.52 ; P=$ 0.002). A dendrogram was constructed (Fig. 5), by combining the different data sets in a common genetic distance matrix, based on Gower's distance and the UPMGA.

With the use of the upper tail approach for the confidence level $\alpha=0.05$, the same three significantly different groups were determined. The cophenetic correlation was equally high $(r=$ 0.96).

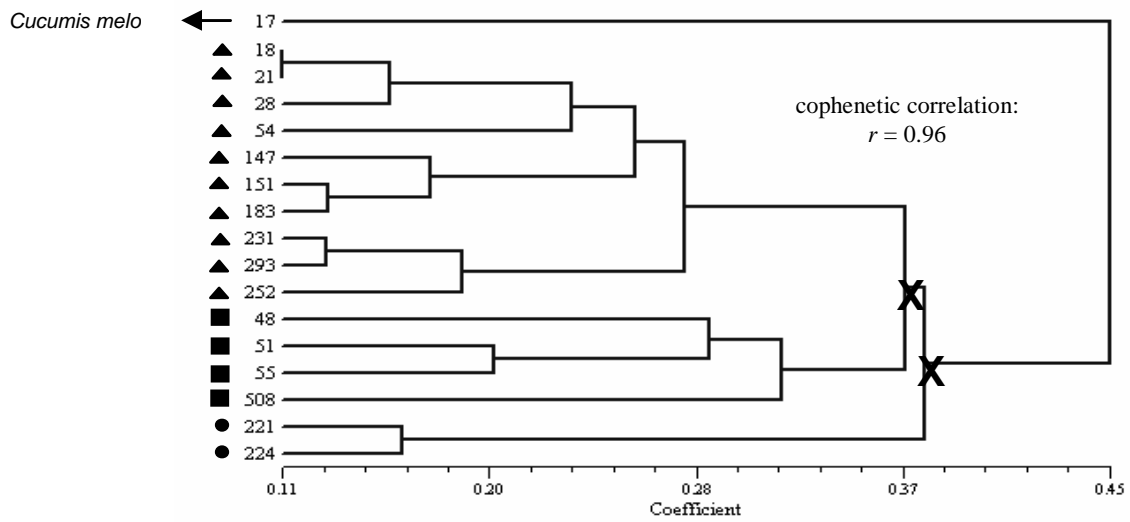

Figure 5 - Dendrogram of 16 squash accessions according to UPGMA analysis of combined data sets (Gower's distance (1971)). 


\section{DISCUSSION}

The identification and utilization of the diverse germplasm is the central issue in plant breeding. Thorough knowledge of the genetic diversity of a crop is necessary for the parental selection that maximizes the genetic improvement. More accurate and complete descriptions of the genotypes and patterns of the genetic diversity could help determine future breeding strategies and facilitate the introgression of diverse germplasm into the current commercial squash genetic base. From all the results obtained, it is clearly evident that there is a considerable variation among the squash accessions, for both the morphophysiological and molecular characteristics. More specifically, as far as the morphology was concerned, the accessions significantly differed in the flower, fruit and seed characteristics. In terms of the response to the pathotypes of $F$. oxysporum, there was a great variation ranging up to complete resistance. Also, the PCA analysis revealed high correlation of the resistances to the two pathotypes $(\mathrm{r}=0.66, P=$ 0.001 , data not shown). At that point, a function character added to the genetic diversity procedure should be mentioned. The usefulness of the resistant accessions offers benefits to breeders by providing a logical general strategy in identifying the best source. Besides, it provides a possibly useful resource by applying a parallel program checking the compatibility of the resistant accessions as rootstocks, enriching thus a friendliness to the environment cultivation system. In the case of the RAPD markers, a very high genetic variation was observed among the indigenous squash accessions, in concordance with the considerable variation revealed at the morphophysiological level. The notably high level of the polymorphism among the accessions (97.44\%) was expected for the different Cucurbita species. Similar high level of the polymorphism (98.28\%) was also reported among different Ocimum species (Singh et al., 2004). The evaluation of 40 morphophysiological characteristics revealed great variation among the accessions and resulted in seven principal components covering more than $80 \%$ of the total variation. The first two principal components were able to explain a cumulative percentage of only $45.79 \%$ of the total variation. According to PCA, the accessions formed two distinct groups, with the codes 221 and 224 to be clearly separated in the biplot diagram (Fig. 1b). Similar results were obtained in the case of cluster analysis (Fig. 2). Thus, after the application of the upper tail approach for the confidence level $\alpha=0.05$, the accessions were classified into two significantly different groups, with the accessions 221 and 224 to constitute a separate group as above.

As compared to the analyses of the morphophysiological traits, the application of the molecular data provided a better resolution, classifying the 16 squash accessions into three significantly different groups. Despite the abovementioned difference in the number of the groups, the two dendrograms, generated from different kind of data, revealed a kind of correlation in the accession grouping. However, Ferriol et al. (2004a) determined very low correlation between the distance matrices using the morphological and molecular data in $C$. moschata germplasm collections. Moreover, Ferriol et al. (2004b) did not find any clear grouping of $C$. maxima accessions according to the morphological traits in the molecular analyses. The discrepancy from the results of the present study could be attributed to the fact that the above mentioned authors applied different molecular markers (SRAP and AFLPs), analyzed the bulked samples instead of individualplant samples, and studied the accessions from only one species in each case. The latter point meant that the differences among their accessions were not expected to be obvious. On the contrary, the accessions of the present study belonged at least to two different species (C. maxima and $C$. moschata). Thus, the differences at the morphophysiological and molecular level were expected to be so enlarged that the probability of a significant correlation between the two different distance matrices was high.

Although the RAPDs resulted in a more detailed grouping, the molecular approach by itself was not capable of assigning the accessions of each species, a practice requiring the exploitation of the morphological data as well. Given the observed correlation, it seemed sound to combine the two kinds of data in order to create a common genetic distance matrix. This approach was further supported by the fact that Mantel's test on the two distance matrices proved to be significant $(r=$ $0.52 ; P=0,002)$ and satisfied the necessity of a true similarity between the different data sets (Mohammadi and Prasanna, 2003). The combined approach, i.e. the morphophysiological and 
molecular data, provided a more robust and biologically meaningful approach.

Finally, based on the combined clustering procedure and focused on the main morphophysiological characteristics, which distinguished the accessions with the use of PCA (Fig. 1a), the 16 accessions could be assigned to three different species, as follows:

Group A: It included the accessions 221 and 224. The accessions had prostrate growth habit, large size of the leaf blade without marbling, large size of the fruit, varying colors, white flesh and large size of the seed. The accessions were completely resistant against Fusarium and belonged to the species C. maxima (Fig. 6a).

Group B: It included the accessions 48, 51, 55 and 508. The accessions had bushy to prostrate growth habit and medium to large size of leaf blade. Some of the accessions appeared marbling. The fruit was small or medium size with white or orange flesh. The accessions were susceptible to Fusarium and belonged to the species C. pepo (Fig. 6b).

Group C: It included the accessions 18, 21, 28, 54, 147, 151, 183, 231, 293 and 252. The accessions had prostrate growth habit, medium to very large size of leaf blade and dark green colour with marbling. The fruit was medium to large size, with orange exterior colour having orange flesh. The accessions were almost completely resistant (except accession 28) against Fusarium and belonged to the species C. moschata (Fig. 6c). In addition, the above mentioned clustering, as well as the assessment of the morphophysiological characteristics, provided the opportunity for the formation of a brief 'identity card' for each accession, including the information about the origin of the accessions and the resistance against F. oxysporum pathotypes (Fig. 6).

Taking all the above into account, it is clearly evident that an integrated approach concerning the conservation of a small part of the indigenous squash accessions was tried to be done. Through this effort, the morphological description and characterization of some local accessions of the squash, almost abandoned from the cultivation, became capable. Moreover, these accessions were assigned on the molecular level and documented precisely by ranging each one to the species they belonged. Finally, the above accessions were evaluated against two pathotypes of the soil born fungus $F$. oxysporum, a procedure that could potentially open the road to the study of these squash accessions as the rootstocks for the melon or watermelon cultivars. Furthermore, the estimated genetic diversity of the accessions increased the use of, and interest in, data already existing and placed a sharp focus on certain data management issues for the gene bank manager.

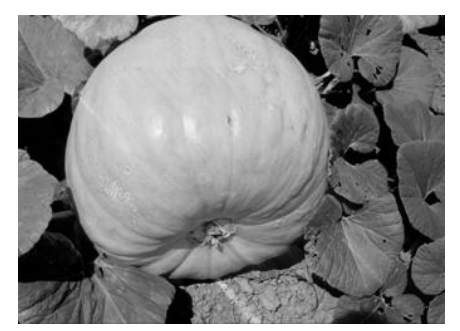

\begin{tabular}{|l|l|}
\hline Accession number & 224 \\
\hline Former classification & Cucurbita maxima \\
\hline Suggested classification & Cucurbita maxima \\
\hline Domain institute & A. R. C. M. T. \\
\hline Date of collection & $21 / 07 / 1999$ \\
\hline Area of origin & Thessaloniki (Livadi) \\
\hline Local name & Kolokitha Kokkini \\
\hline Seed yield (g) & 448.81 \\
\hline $\begin{array}{l}\text { Resistance against Fusarium oxysporum } \\
\text { f.sp. radicis-cucumerinum }\end{array}$ & $100 \%$ resistant plants \\
\hline $\begin{array}{l}\text { Resistance against Fusarium oxysporum } \\
\text { f.sp. melonis }\end{array}$ & $100 \%$ resistant plants \\
\hline
\end{tabular}



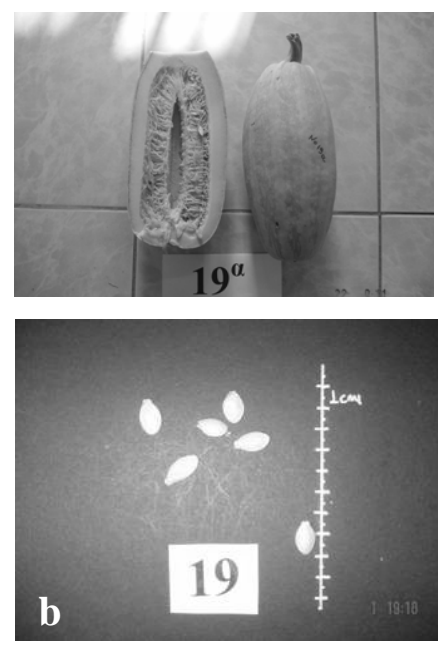

\begin{tabular}{|l|l|}
\hline Accession number & 508 \\
\hline Former classification & Cucurbita maxima \\
\hline Suggested classification & Cucurbita pepo \\
\hline Domain institute & Greek Gene Bank \\
\hline Date of collection & $08 / 06 / 1999$ \\
\hline Area of origin & Pella (Almopia) \\
\hline Local name & - \\
\hline Seed yield (g) & 275.39 \\
\hline $\begin{array}{l}\text { Resistance against Fusarium oxysporum f.sp. } \\
\text { radicis-cucumerinum }\end{array}$ & $33,3 \%$ resistant \\
\hline & $66,6 \%$ dead plants \\
\hline $\begin{array}{l}\text { Resistance against Fusarium oxysporum f.sp. } \\
\text { melonis }\end{array}$ & $100 \%$ resistant plants \\
& \\
\hline
\end{tabular}

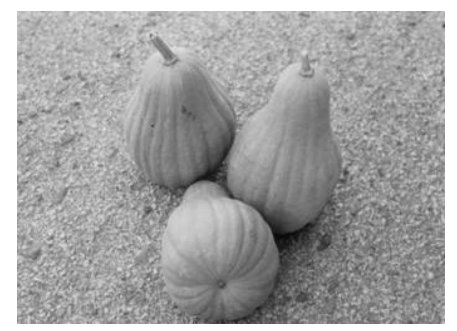

\begin{tabular}{|l|l|}
\hline Accession number & 21 \\
\hline Former classification & Cucurbita moschata \\
\hline Suggested classification & Cucurbita moschata \\
\hline Domain institute & A. R. C. M. T. \\
\hline Date of collection & $05 / 06 / 1999$ \\
\hline Area of origin & Chalkidiki (Galatista) \\
\hline Local name & Kalkabaki \\
\hline Seed yield (g) & 600.00 \\
\hline $\begin{array}{l}\text { Resistance against Fusarium oxysporum } \\
\text { f.sp. radicis-cucumerinum }\end{array}$ & $100 \%$ resistant plants \\
\hline $\begin{array}{l}\text { Resistance against Fusarium oxysporum } \\
\text { f.sp. melonis }\end{array}$ & $100 \%$ resistant plants \\
\hline
\end{tabular}

Figure 6 - 'Identity card' for a typical accession of $C$. maxima group (acc. code 224, a), C. pepo group (acc. code 508, b) and C. moschata group (acc. code 21, c).

\section{ACKNOWLEDGEMENTS}

The authors are grateful to Prof. K. KlonariTzavela for her help on the phytopathological part of this research, and to Ass. Prof. F.A. Aravanopoulos for his helpful comments on statistical procedure. We also thank Dr. N. Stavropoulos and Dr. S. Samaras, researchers in the Greek Gene Bank, for supplying the plant material used in this study.

\section{RESUMO}

A abobrinha de inverno compõe um cultivo agrícola com valor econômico determinado exercendo, no entanto, um papel importante em zonas caracterizadas por um cultivo menos intensivo.

$\mathrm{Na}$ Grécia, o cultivo da abobrinha se baseia, principalmente, em variedades locais conservadas a muitos anos por agricultores locais. Uma parte do cultivo nuclear da abobrinha, que é conservada pelo Banco Grego de Genes, foi melhorada utilizando-se dados morfológicos e moleculares, especialmente dezesseis cultivos de abobrinha classificados incompletamente, que foram diferenciados apenas com base em características morfológicas, em relação a uma avaliação à resistência contra o Fusarium Oxysporum, em dois isolamentos. Foi realizada uma análise molecular utilizando DNA Polimórficos Casual Amplificados índices (RAPDs), revelando um alto nível de polimorfismo. 
Para estudar a diversidade genética entre a coleção de abobrinhas, um procedimento de agrupamento foi realizado usando-se o algoritmo U.P.G.M.A. Dois dendrogramas independentes, um morfofisiológico e outro para dados moleculares, foram coletados, classificando as coleções em dois e três grupos básicos, respectivamente.

Apesar do número diferente dos grupos, foram introduzidas muitas semelhanças entre os dois dendrogramas e um terceiro dendrograma foi produzido como resultado da combinação dos dois primeiros, baseado na distância de Gower e no algoritmo de agrupamento U.P.G.M.A. Para determinar o número ótimo dos grupos, a aproximação "upper tail" foi aplicada. O grupo mais aceitável das coleções foi conseguido usando-se índices RAPD, assim como a combinação dos dois grupos de dados diferentes, classificando as coleções em três grupos consideravelmente diferentes.

Os grupos que correspondem às três espécies cultivadas diferentemente, que correspondem às três espécies cultivadas diferentemente por C.máxima Duch., C.moschata Duch. e C. pepo L. além disso, os mesmos resultados foram conseguidos usando-se a "Principal Component Analysis".

\section{REFERENCES}

Ajmone-Marsan, P.; Livini, C.; Messmer, M. M.; Melchinger, A. E. and Motto, M. (1992), Cluster analysis of RFLP data from related maize inbred lines of the BSSS and LSC heterotic groups and comparison with pedigree data. Euphytica, 60, 139148.

Baranek, M.; Stift, G.; Vollmann, J. and Lelley, T. (2000), Genetic diversity within and between the species Cucurbita pepo, C, moschata and C. maxima as revealed by RAPD markers. Cucurbit. Genet. Coop. Rep., 23, 73-77.

Chung, H. D.; Youn, S. J. and Choi, Y. J. (1998), Ecological and morphological characteristics of the Korean native squash (Cucurbita moschata). (In Korean with English abstract), J. Kor. Soc. Hort. Sci., 39 (4), 377-384.

Ferriol, M.; Picó, B. and Nuez, F. (2003), Genetic diversity of some accessions of Cucurbita maxima from Spain using RAPD and SBAP markers. Genet. Resour. Crop Evol., 50, 227-238.

Ferriol, M.; Picó, B.; Fernández, P. and Nuez, F. (2004a), Molecular diversity of a germplasm collection of squash (Cucurbita moschata) determined by SRAP and AFLP markers. Crop Sci., 44, 653-664.

Ferriol, M.; Picó, B. and Nuez, F. (2004b), Morphological and molecular diversity of a collection of Cucurbita maxima landraces. J. Amer. Soc. Hort. Sci., 129 (1), 60-69.

Franco, J.; Crossa, J.; Villaseñor, J.; Taba, S. and Eberhart, S. A. (1997), Classifying Mexican maize accessions using hierarchical and density search methods. Crop Sci., 37, 972-980.

Franco, J.; Crossa, J.; Villaseñor, J.; Taba, S. and Eberhart, S. A. (1998), Classifying genetic resources by categorical and continuous variables. Crop Sci., 38, 1688-1696.

Franco, J.; Crossa, J.; Ribaut, J. M.; Betran, J.; Warburton, M. L. and Khairallah, M. (2001), A method for combining molecular markers and phenotypic attributes for classifying plant genotypes. Theor. Appl. Genet., 103, 944-952.

Gower, J. C. (1971), A general coefficient of similarity and some of its properties. Biometrics, 27, 857-874.

Gwanama, C.; Labuschagne, M. T. and Botha, A. M. (2000), Analysis of genetic variation in Cucurbita moschata by random amplified polymorphic (RAPD) markers. Euphytica, 113, 19-24.

Koutsika-Sotiriou, M.; Traka-Mavrona, E.; Tsivelikas, A. L.; Mpardas, G.; Mpeis, A. and Klonari, E. (2004), Use of genetic resources in a dual approach system toward selecting improved scion/rootstock grafting combinations of melon (Cucumis melo) on Cucurbita spp. In: Progress in Cucurbit Genetics and Breeding Research, eds. A. Lebeda and H. S. Paris, Proc. of Cucurbitaceae 2004, the $8^{\text {th }}$ EUCARPIA meeting on Cucurbit Genetics and Breeding, Olomouc, Czech Republic, July 12-17, 2004, pp. 163-167.

Leach, J. G. and Currence, T. M. (1938), Fusarium wilt of muskmelon in Minnesota. Minn. Agric. Exp. Stn. Bull., 129.

Mantel, N. A. (1967), The detection of disease clustering and a generalized regression approach. Cancer Res., 27, 209-220.

Milligan, G. W. and Cooper, M. (1985), An examination of procedures for determining the number of clusters in a data set. Psychometrica, 50, 159-179.

Mohammadi, S. A. and Prasanna, B. M. (2003), Analysis of genetic diversity in crop plants - Salient statistical tools and considerations. Crop Sci., 43, 1235-1248.

Nei, M. (1972), Genetic distance between populations. Amer. Natur., 106, 283-292.

Rios, H.; Fernández, A. and Batista, O. (1997), Cuban pumpkin genetic variability under low input conditions. Cucurbit. Genet. Coop. Rep., 20, 48-49.

Rogers, S. O. and Bendich, A. J. (1988), Extraction of DNA from plant tissues. Plant Molecular Biology Manual, A6, 1-10. 
Robinson, R. W. and Decker-Walters, D. S. (1997), Cucurbits. Crop Production Science in Horticulture. Cab International, New York.

Rohlf, F. J. (2000), NTSYS pc: Numerical Taxonomy and Multivariate Analysis System. Version 2.1. Exeter Software, New York.

Russel, J. R.; Fuller, J. D.; Macaulay, M.; Hatz, B. G.; Jahoor, A.; Powell, W. and Waugh, R. (1997), Direct comparison of levels of genetic variation among barley accessions detected by RFLPs, AFLPs, SSRs, and RAPDs. Theor. Appl. Genet., 95, 714-722.

Sambrook, J.; Fritsch. E. F. and Maniatis, T. (1989), Molecular Cloning. A Laboratory Manual. Cold Spring Harbor Laboratory Press, New York.

Singh, A. P.; Dwivedi, S.; Bharti, S.; Srivastava, A.; Singh, V. and Khanuja, S. P. S. (2004), Phylogenetic relationships as in Ocimum revealed by RAPD markers. Euphytica, 136, 11-20.

Traka-Mavrona, E.; Koutsika-Sotiriou, M. and Pritsa Th. (2000), Response of squash (Cucurbita spp.) as rootstock for melon (Cucumis melo L.). Sci. Hort., 83, 353-362.
UPOV, (1996), Guidelines for the conduct of tests for distinctness, uniformity and stability of Pumpkin (Cucurbita maxima Duch.), TG/155/3. Geneva, Switzerland.

Vakalounakis, D. J. (1996), Root and stem rot of cucumber caused by Fusarium oxysporum f.sp. radicis-cucumerinum f.sp. nov. Plant Disease, 80, 313-316.

Wessel-Beaver, L. (2000), Evidence for the center of diversity of Cucurbita moschata in Colombia. Cucurbit. Genet. Coop. Rep., 23, 54-55.

Youn, S. J. and Chung, H. D. (1998), Genetic relationship among the local varieties of the Korean native squashes (Cucurbita moschata) using RAPD technique. (In Korean with English abstract), J. Kor. Soc. Hort. Sci., 39, 517-521.

Received: September 06, 2006; Revised: February 12, 2007; Accepted: May 29, 2008. 